\title{
Response of Soil Microbial Communities to Different Cultivation Systems in Controlled Horticultural Land
}

\author{
You-Seok Lee, Jeong-Hwa Kang, Kyeong-Ju Choi, Seong Tae Lee ${ }^{1}$, Eun-Seok Kim ${ }^{1}$, \\ Won-Doo Song ${ }^{1}$, and Young Han Lee ${ }^{1 *}$ \\ Jeollanam-do Agricultural Research and Extension Services, Naju, 520-715, Korea \\ ${ }^{1}$ Gyeongsangnam-do Agricultural Research and Extension Services, Jinju, 660-370, Korea
}

\begin{abstract}
Ester-linked fatty acid methyl ester (EL-FAME) profiles were used to describe differences in soil microbial communities influenced by conventional farming system (CFS), and organic farming system (OFS) in controlled horticultural land. Soil physicochemical properties and soil microbial communities were determined in the experimental fields. Higher organic matter content in OFS reduced soil bulk density which in tum increased the soil porosity. Generally, soil chemical properties in OFS were higher than those of CFS, but EC value in OFS was significantly lower than that of CFS. With the exception of Fe content, other macronutrient contents and $\mathrm{pH}$ in both farming system decreased with the soil depth. Soil microbial biomass of OFS was approximately 1.3 times in topsoil and 1.8 times in subsoil higher than those of CFS. Lower ratios of cy17:0 to 16:1 $\omega 7 \mathrm{c}$ and cy19:0 to 18:1 $\omega 7 \mathrm{c}$ were found in the CFS soils than the OFS soils, indicating that microbial stress decreased. The ratio of MUFA to SFA was higher in OFS due to organic input to the soil. In principal components analysis (PCA), the first variable accounted for $54.3 \%$, while the second for $27.3 \%$, respectively. The PC1 of the PCA separated the samples from CFS and OFS, while the PC2 of the PCA separated the samples from topsoil and subsoil. EL-FAMEs with the positive eigenvector coefficients for PC1 were cy17: 0 to 16:1 $\omega 7 \mathrm{c}$ ratio, cy19:0 to 18:1 $\omega 7 \mathrm{c}$ ratio, soil $\mathrm{pH}$, soil organic matter, and soil $\mathrm{NO}_{3}-\mathrm{N}$ content. Our findings suggest that the shifting cy19:0 to 18:1 $\omega 7 \mathrm{c}$ ratio should be considered as potential factors responsible for the clear microbial community differentiation observed between different cultivation systems and soil depth in controlled horticultural land.
\end{abstract}

Key words: Ester-linked fatty acid methyl ester (EL-FAME), Microbial community, Organic system

\section{Introduction}

Plant growth in organic systems greatly depends on the functions of soil microbes particularly in nutrient supply. In comparison with conventional farming, organic farming has potential benefits in promoting soil structure formation (Wright et al.,1999), enhancing soil biodiversity (Mäder et al., 2002; Oehl et al., 2003), alleviating environmental stress (Altieri, 2002), and improving food quality and safety (Torjusen et al., 2001). Because nutrient supply and pest control largely depend on organic inputs and biological processes in organic systems (Cobb et al., 1999), organic farming avoids the inputs of synthetic chemicals and their

\footnotetext{
Received : January 19. 2011 Accepted : February 21. 2011

*Corresponding author : Phone: +82557716413

E-mail: lyh2011@korea.kr
}

harmful effect.

Bulk density is closely related with soil porosity and penetration resistance, and it also affects field soil water content. Higher bulk density with lower porosity decreases soil aeration, water infiltration and percolation. Besides, the higher bulk density, the greater penetration resistance, which is restricting plant root growth (Cassel, 1982).

Soil microbial function is best evaluated at the field scale within the context of the soil environment and the crop. Changes in the community of soil microbes may reflect changes in soil quality. It has been shown that different soil management practices affected activities of soil microorganisms (Patra et al., 2008). Thus, enhancing soil microbial community have become fundamental aspects in sustainable agriculture. Practices associated with organic farming have a positive effect on soil microbial community and soil aggregation but 
there is little evidence of a link between AMF and glomalin in paddy (Stark et al., 2007; Islam et al., 2009). Since its introduction, the MIDI technique has been used to assess storage effects on bacterial isolates (Haldeman et al., 1994), to characterize root-associated microorganisms (Graham et al., 1995; Sicilaino and Germida, 1998) and to describe microbial communities of agricultural soils (Cavigelli e al., 1995; Buyer and Drinkwater, 1997; Ibekwe and Kennedy, 1998) and soils amended with various organic and inorganic compounds (Fries et al., 1997; Macalady et al., 1998). Fatty acid methyl ester (FAME) profiles of soils can be compared using multivariate statistical techniques to reveal differences in microbial communities (Macalady et al., 1998; Frostegård and Bååth, 1996; Rajendran et al., 1994). FAME composition provides a quantitative insight into the microbial community, which can be sampled from the environment without the need for isolation (Pennanen, 2001). In addition, using FAME analysis to differentiate between bacterial and fungal biomass in the soil enables the estimation of the biomass of both organism groups with a single technique in the same soil sample (Frostegård and Bååth, 1996), which has a greater advantage over other methods such as DNA analysis. Analysis of ester-linked (EL) FAME was used to evaluate variation in the soil microbial community structure and had advantages compared with the MIDI method (Schutter and Dick, 2000). Also, EL-FAME analysis is relatively simple and fast, and its effectiveness for assessing community structure has been demonstrated. The EL-FAME method successfully characterized microbial communities of several grass seed field soils and placed communities into groupings similar to those generated by a DNAbased method (Ritchie et al., 2000). Therefore, coordinating microbial community data with key soil biogeochemical and environmental variables may give us some insight into new factors which are important for sustainable agriculture.

The objective of this study was to assess the impact of conventional and organic farming systems on soil environment and structures of soil microbial communities in controlled horticultural land. We hypothesized that the structure of soil microbial community might be altered in response to higher soil organic matter content of organic cultivation system than that of conventional farming system.

\section{Materials and Methods}

Experimental site description The experiment was conducted at conventionally and organically cultivated farms in Jangsa-ri $\left(35^{\circ} 13^{\prime} \mathrm{N}, 128^{\circ} 08^{\prime} \mathrm{E}\right)$, Geumsanmyeon, Jinju City, Gyeongnam, Korea. In both fields, red pepper (Capsicum annum L.) was transplanted under plastic film houses on October 2, 2007 and pods were harvested until June 30, 2008. Organically managed soil was certified by the National Agricultural Products Quality Management Service of Korea to cultivate organic agricultural products (Certified No. 17-03-1-1). The experimental treatments were arranged in a randomized complete block design at a size of $100 \mathrm{~m}^{2}(10 \mathrm{~m}$ $\times 10 \mathrm{~m}$ ) with replicates. To supplement organic matter and enhance soil health, paddy seed $\left(0.2 \mathrm{~kg} \mathrm{ha}^{-1}\right)$ was directly sown in the organic farming around July every year. Then the seedlings were buried under soil to a depth of $15 \mathrm{~cm}$ by rotary cultivator in early September just before plowing for next crop every year.

\section{Determination of physical and chemical properties} of soil Three replications of topsoil and subsoil samples were taken from each plot between 0 and $30 \mathrm{~cm}$ depths on June 30, 2008. Bulk density was determined by using a soil core method (Blake and Hartge, 1986a). Soil particle density was determined by the Pycnometer Method (Blake and Hartge, 1986b) to estimate soil porosity. Soil Porosity was determined from the results of soil bulk density and particle density using a following equation: $P=\left(1-\rho_{s} / \rho_{p}\right) \times 100$, where $P$ is the soil porosity $(\%), \rho_{\mathrm{s}}$ is the soil bulk density $\left(\mathrm{Mg} \mathrm{m}^{-3}\right)$ and $\rho_{\mathrm{p}}$ is the soil particle density $\left(\mathrm{Mg} \mathrm{m}^{-3}\right)$. The water content was calculated as the mass of water in the soil sample using a following equation:

$$
\begin{aligned}
\mathrm{W}= & (\text { mass of wetting soil }- \text { mass of drying soil }) \\
& / \text { core volume } \times 100, \text { where } \mathrm{W} \text { is water content }(\%) .
\end{aligned}
$$

Soil samples were air-dried and sieved to obtain less than $2 \mathrm{~mm}$ in particle diameter.

Then, chemical properties of the soil were determined using standard methods of RDA (NIAST, 2003).

Determination of soil microbial communities The EL-FAME procedure for determination of soil microbial communities employs a mild alkaline methanolysis 
Table 1. Physical properties of affected topsoil and subsoil at the different cultivation systems.

\begin{tabular}{|c|c|c|c|c|c|c|c|c|}
\hline \multirow[t]{2}{*}{ Physical property } & \multicolumn{2}{|c|}{$\mathrm{CFS}^{\dagger}$} & \multicolumn{2}{|c|}{$\mathrm{OFS}^{\ddagger}$} & \multirow{2}{*}{$\begin{array}{c}\text { LSD } \\
(p<0.05)\end{array}$} & \multicolumn{3}{|c|}{ Significance $^{\S}$} \\
\hline & Topsoil & Subsoil & Topsoil & Subsoil & & Farm & Depth & Farm $\times$ Depth \\
\hline Bulk density $\left(\mathrm{Mg} \mathrm{m}^{-3}\right)$ & 1.05 & 1.12 & 0.99 & 1.08 & 0.088 & NS & $*$ & NS \\
\hline Porosity (\%) & 60.3 & 57.8 & 62.8 & 59.4 & 3.30 & NS & $*$ & NS \\
\hline Water content $(\%)$ & 26.5 & 29.2 & 23.5 & 25.0 & NS & NS & NS & NS \\
\hline
\end{tabular}

${ }^{\dagger}$ CFS: Conventional farming system, ${ }^{\ddagger}$ OFS: Organic farming system, ${ }^{\S}$ Significant effects were obtained from two-way analysis of variance: *, at $p<0.05$ and $\mathrm{NS}$, not significant.

method, which is thought to extract EL fatty acids but not free fatty acids. This particular method was modified using EL-FAME extraction (Schutter and Dick, 2000) for soil analysis and consists of four reagents and four steps. In the first step, $15 \mathrm{~mL}$ of $0.2 \mathrm{M}$ $\mathrm{KOH}$ in methanol were added to a $35 \mathrm{~mL}$ teflon-lined, screw-cap glass centrifuge tube containing $3 \mathrm{~g}$ of soil. The contents of the tubes were mixed during $20 \mathrm{sec}$, and incubated at $37^{\circ} \mathrm{C}$ for $1 \mathrm{~h}$ (vortexed every $10 \mathrm{~min}$ ), during which ester-linked fatty acids were released and methylated. In the second step, $3 \mathrm{~mL}$ of $1.0 \mathrm{M}$ acetic acid were added to neutralize the $\mathrm{pH}$ of the tube contents. FAMEs were partitioned into an organic phase by adding $10 \mathrm{~mL}$ of hexane and then vortexed for $60 \mathrm{sec}$ followed by centrifugation at $2,000 \times \mathrm{g}$ for $20 \mathrm{~min}$. No washing step was needed at this point in contrast to the MIDI method, which requires that all acidic residues be removed from the organic phase to prevent damage to the gas chromatography (GC) column. After the hexane layer $(5 \mathrm{~mL})$ was transferred to a clean glass test tube, the hexane was evaporated under a stream of $\mathrm{N}_{2}$ for 40 minutes. In the final step, FAMEs and internal standard 19:0 $30 \mu \mathrm{L}$ were dissolved in $170 \mu \mathrm{L}$ of $1: 1$ hexane: methyl-tert butyl ether and transferred into a $250 \mu \mathrm{L}$ glass insert and placed in a GC vial for analysis. Results were analyzed by the MIDI system as GC analysis with a Agilent $6890 \mathrm{~N}$ (Agilent Technologies, USA) equipped with an HP-ULTRA 2 capillary column $(25 \mathrm{~m}$ $\times 0.2 \mathrm{~mm} \times 0.33 \mu \mathrm{m}$ film thickness, Agilent Technologies, USA) and a flame ionization detector. The temperature program ramped from 170 to $270^{\circ} \mathrm{C}$ at $5^{\circ} \mathrm{C}$ per min, with $2 \mathrm{~min}$ at $270^{\circ} \mathrm{C}$ between samples to clean the column. Fatty acid analysis was applied for MIDI software program package (MIDI, Inc., Newark, DE), systematical similarity relation between each microbe was analyzed. Individual fatty acids have been used as signatures for various groups of microorganisms (Pankhurst et al, 2002; Hamel et al., 2006). The fatty acids i15:0, a15:0, 15:0, i16:0, 16:1 $\omega 9,16: 1 \omega 7$, i17:0, a17:0, 17:0, cy17:0, 18:1 $1 \mathrm{c}$, and cy19:0 were chosen to represent bacterial FAMEs (Macalady et al., 1998; Schutter and Dick, 2000). The fatty acids $16: 1 \omega 7 \mathrm{c}, 18: 1$ $\omega 7 \mathrm{c}$, cy17:0, and cy19:0 were chosen to represent Gram-negative bacteria (Zelles, 1997). The branched, saturated FAMEs i15:0, a15:0, i16:0, i17:0, and a17:0 were chosen to represent Gram-positive bacteria (Zelles, 1997). The FAME 10Me18:0 was used to indicate soil actinomycetes (Kroppenstedt, 1985). Soil FAME 18:1 $\omega$ $9 \mathrm{c}$ and 18:2 $\omega 6 \mathrm{c}$ were used as indicators of saprophytic fungi (Bradleya et al., 2006). The FAME 16:1 $\omega 5 \mathrm{c}$ was indicator of arbuscular mycorrhizal fungi (AMF) by reported Frostegård et al. (1993), Olsson et al. (1998), and Balser et al. (2005). The ratios between the bacterial fatty acids cy 17:0 and cy19:0 and their metabolic precursors, $16: 1 \omega 7 \mathrm{c}$ and $18: 1 \omega 7 \mathrm{c}$, and total monounsaturated (MUFA) to total saturated (SFA) have previously been used as indicators of nutritional stress in bacterial communities (Bossio and Scow, 1998; Grogan and Cronan, 1997; Guckert et al., 1986; Kieft et al., 1997).

Statistical analysis All data were statistically performed using SAS software version 9.3 for window (2006). Comparison of individual soil physic-chemical and microbiological variables measured was performed using two-way ANOVA. In cases where significant effects of the interactions between the independent variables were detected, the $F$-test was used to detect and separate the mean treatment differences at $0.1,1.0$, and $5.0 \%$ level of significance $(p<0.001,0.01$ and 0.05$)$, respectively. Also, differences in abundance were tested using Fisher's least significant difference procedure. For each EL-FAME biomarkers and soil physico-chemical properties were analyzed by principal components analysis (PCA) to determine the overall effects of OFS and CFS on soil microbial community. 


\section{Results and Discussion}

Soil physical and chemical properties Soil physical properties as affected OFS and CFS at the different soil depth are presented in Table 2. The values of soil bulk density ranged from 1.05 to $1.12 \mathrm{Mg} \mathrm{m}^{3}$ in CFS and from 0.99 to $1.08 \mathrm{Mg} \mathrm{m}^{3}$ in OFS. The values of soil bulk density in topsoil and subsoil from OFS showed similar trend to those from CFS. A similar result were reported by Reganold et al. (1987), which was that bulk densities of the organically and conventionally-farmed soils were not significantly different. The soil bulk density showed a significant effect of soil depth $(p<0.05)$, but there was no significant interaction between farming system and soil depth. In relation to soil compaction, soil porosity was also determined in the experimental fields because the soil porosity is inversely related to soil bulk density. Mäder et al. (2002) reported that soil aggregate stability related with bulk density and porosity was higher in the organic plots than in the conventional plots. The values of soil porosity in the experimental fields ranged between 60.3 for topsoil and $57.8 \%$ for subsoil in CFS and between $62.8 \%$ for topsoil and $59.4 \%$ for subsoil in OFS, and they might not be also significantly different among the cultivation systems, except in soil depth $(p<0.05)$, which were higher in OFS compared with CFS at the same soil depth. As relating to the bulk density and soil porosity, soil water content was also measured. The water contents ranged from $26.5 \%$ for topsoil to $29.2 \%$ in CFS and from $23.5 \%$ for topsoil to $25.0 \%$ for subsoil in OFS. The values of water contents were not different among the different cultivation systems, soil depth, and those interactions. Higher organic matter content in OFS reduced soil bulk density which in turn increased the soil porosity.
Soil chemical properties were affected by different cultivation systems (Table 2). Most soil chemical properties except soil $\mathrm{pH}$ at topsoil and subsoil have significant relation between OFS and CFS $(p<0.05)$. Generally, soil chemical properties in OFS were higher than those of CFS, but EC value in OFS was significantly low compared to that of CFS. In particular, soil organic matter in OFS was 1.5 times higher than that of CFS. It is very similar to result by Reganold et al. (1987) that the organically-farmed soils had significantly higher organic matter content than the conventionally-farmed soil. Organic matter has a profound impact on soil quality; it encourages granulation, nutrient supply, and soil organism activity, and improves soil fertility and productivity (Allison, 1973; Johnston, 1986). The values of chemical properties in OFS and CFS were slightly low in deeper soil depth. In contrast, the Fe contents of soils in OFS and CFS were higher in subsoil than those of topsoil. Clark et al (1998) found that concentrations of carbon, phosphorus, potassium, calcium, and magnesium were greater in soils with incorporated manures and cover crops.

Soil microbial community Coordinating microbial community data with key soil biogeochemical and environmental variables may give us some insight into what factors are important for sustainable organic farming system (Hamman et al., 2007). The microbial biomass of EL-FAMEs was shown in Table 3. The all of microbial biomass were significantly higher in OFS compared with CFS. The relation of different farming systems as microbial biomass showed highly significant bacteria $(p<0.001)$, Gram-positive bacteria $(p<0.001)$, Gram-negative bacteria $(p<0.001)$, actinomycetes $(p<$ $0.05)$, fungi $(p<0.001)$, AMF ( $p<0.001)$, Gram-positive to Gram-negative bacteria $(p<0.001)$, fungi to bacteria

Table 2. Chemical properties of affected topsoil and subsoil at the different cultivation systems.

\begin{tabular}{|c|c|c|c|c|c|c|c|c|c|c|c|c|c|}
\hline \multicolumn{2}{|c|}{ Chemical property } & \multirow[t]{2}{*}{$\mathrm{pH}$} & \multirow[t]{2}{*}{$\mathrm{EC}$} & \multirow[t]{2}{*}{$\mathrm{OM}$} & \multirow[t]{2}{*}{ Av. $\mathrm{P}_{2} \mathrm{O}_{5}$} & \multicolumn{4}{|c|}{ Exch. Cation } & \multirow[t]{2}{*}{$\mathrm{Fe}$} & \multirow[t]{2}{*}{$\mathrm{Mn}$} & \multirow[t]{2}{*}{$\mathrm{Zn}$} & \multirow[t]{2}{*}{$\mathrm{NO}_{3}-\mathrm{N}$} \\
\hline & & & & & & $\mathrm{K}$ & $\mathrm{Ca}$ & $\mathrm{Mg}$ & $\mathrm{Na}$ & & & & \\
\hline \multirow{3}{*}{$\mathrm{CFS}^{\dagger}$} & & $(1: 5)$ & $\mathrm{dS} \mathrm{m}^{-2}$ & $\mathrm{~g} \mathrm{~kg}^{-1}$ & $\mathrm{mg} \mathrm{kg}^{-1}$ & $\begin{array}{ll}----- \\
---\end{array}$ & $\mathrm{cmol}_{\mathrm{c}}$ & $\mathrm{g}^{-1}-$ & $\begin{array}{c}--- \\
--\end{array}$ & ------ & mg & $\mathrm{kg}^{-1}-$ & ------- \\
\hline & Topsoil & 6.7 & 2.15 & 29 & 1,537 & 1.35 & 9.1 & 2.9 & 0.41 & 67.2 & 20.2 & 13.7 & 67 \\
\hline & Subsoil & 6.6 & 1.48 & 28 & 1,420 & 1.24 & 8.3 & 2.5 & 0.29 & 75.8 & 21.6 & 13.3 & 59 \\
\hline \multirow[t]{2}{*}{$\mathrm{OFS}^{\ddagger}$} & Topsoil & 6.7 & 1.26 & 45 & 1,976 & 1.83 & 10.9 & 3.2 & 0.35 & 84.5 & 32.2 & 29.9 & 113 \\
\hline & Subsoil & 6.7 & 1.03 & 43 & 1,987 & 1.79 & 10.7 & 3.0 & 0.29 & 87.7 & 29.2 & 30.0 & 142 \\
\hline \multicolumn{2}{|c|}{ LSD $(p<0.05)$} & 0.03 & 0.08 & 4.2 & 98.5 & 0.07 & 0.29 & 0.07 & 0.01 & 3.88 & 1.80 & 0.94 & 46.9 \\
\hline
\end{tabular}

${ }^{\dagger} \mathrm{CFS}$ : Conventional farming system, ${ }^{\ddagger} \mathrm{OFS}$ : Organic farming system. 
Table 3. Soil microbial community of topsoil and subsoil expressed as nmol at the different cultivation systems.

\begin{tabular}{|c|c|c|c|c|c|c|c|c|}
\hline \multirow[t]{2}{*}{ Biomarker (nmol g ${ }^{-1}$ ) } & \multicolumn{2}{|c|}{$\mathrm{CFS}^{\dagger}$} & \multicolumn{2}{|c|}{$\mathrm{OFS}^{\ddagger}$} & \multirow{2}{*}{$\begin{array}{c}\text { LSD } \\
(p<0.05)\end{array}$} & \multicolumn{3}{|c|}{ " Significance $^{\S}$} \\
\hline & Topsoil & Subsoil & Topsoil & Subsoil & & System & Depth & System $\times$ Depth \\
\hline Bacteria & 95.0 & 74.2 & 127.5 & 130.6 & 6.26 & $* * *$ & $* *$ & $* * *$ \\
\hline Gram-positive bacteria & 49.4 & 39.8 & 63.7 & 67.4 & 3.61 & $* * *$ & $*$ & $* * *$ \\
\hline Gram-negative bacteria & 37.2 & 28.0 & 52.0 & 51.6 & 2.38 & $* * *$ & $* * *$ & $* * *$ \\
\hline Actinomycetes & 5.3 & 3.0 & 5.2 & 5.3 & 1.26 & $*$ & $*$ & $*$ \\
\hline Fungi & 56.8 & 33.6 & 69.5 & 71.4 & 3.35 & $* * *$ & $* * *$ & $* * *$ \\
\hline Arbuscular mycorrhizal fungi & 12.5 & 8.4 & 14.7 & 13.7 & 1.80 & $* * *$ & $* *$ & $*$ \\
\hline Actinomycetes:bacteria & 0.06 & 0.04 & 0.04 & 0.04 & 0.014 & NS & NS & NS \\
\hline $\mathrm{Gm}+\mathrm{Gm}-$ bacteria & 1.33 & 1.42 & 1.22 & 1.31 & 0.048 & $* * *$ & $* * *$ & NS \\
\hline Fungi:Bacteria & 0.60 & 0.45 & 0.55 & 0.55 & 0.020 & $*$ & $* * *$ & $* * *$ \\
\hline Monounsaturated fatty acid & 66.0 & 46.1 & 90.1 & 89.6 & 4.03 & $* * *$ & $* * *$ & $* * *$ \\
\hline Saturated fatty acid & 113.0 & 91.4 & 142.8 & 155.0 & 5.14 & $* * *$ & $*$ & $* * *$ \\
\hline
\end{tabular}

${ }^{\dagger}$ CFS: Conventional farming system, ${ }^{\ddagger}$ OFS: Organic farming system, ${ }^{\S}$ Significant effects were obtained from two-way analysis of variance: *, at $p<0.05$; **, at $p<0.01$; **, at $p<0.001$ and NS, not significant.

$(p<0.05)$, MUFA $(p<0.001)$, and SFA $(p<0.001)$, but there was no significant ratio of actinomycetes to total bacteria. Similarly, the relation between topsoil and subsoil showed highly significant bacteria $(p<0.01)$, Gram-positive bacteria $(p<0.05)$, Gram-negative bacteria $(p<0.001)$, actinomycetes $(p<0.05)$, fungi $(p<0.001)$, AMF $(p<0.01)$, Gram-positive to Gram-negative bacteria $(p<0.001)$, fungi to bacteria $(p<0.001)$, MUFA $(p<0.001)$, and SFA $(p<0.05)$. The interaction between farming system and soil depth showed highly significant bacteria $(p<0.001)$, Gram-positive bacteria $(p<0.001)$, Gramnegative bacteria $(p<0.001)$, actinomycetes $(p<0.05)$, fungi $(p<0.001)$, AMF $(p<0.05)$, MUFA $(p<0.001)$, and SFA $(p<0.001)$, but there was no significant ratio of actinomycetes to total bacteria and Gram-positive bacteria to Gram-negative bacteria. The values of total FAMEs in the experimental soils ranged between 324 $\mathrm{nmol} \mathrm{g}^{-1}$ for topsoil and $242 \mathrm{nmol} \mathrm{g}^{-1}$ for subsoil in CFS and between $413 \mathrm{nmol} \mathrm{g}^{-1}$ for topsoil and $432 \mathrm{nmol} \mathrm{g}^{-1}$ for subsoil in OFS, and they were significantly different among the different cultivation systems $(p<0.001)$, soil depth $(p<0.001)$, and their interaction $(p<0.001)$ effect (data not shown). In other words, soil microbial biomass of OFS was approximately 1.3 times in topsoil and 1.8 times in subsoil higher than those of CFS.

The ratios of cy17:0 to $16: 1 \omega 7 \mathrm{c}$, cy19:0 to $18: 1 \omega 7 \mathrm{c}$, and MUFA to SFA have previously been used as indicators of nutritional stress in bacterial communities (Bossio and Scow, 1998; Grogan and Cronan, 1997; Guckert et al., 1986; Kieft et al., 1997). In presented
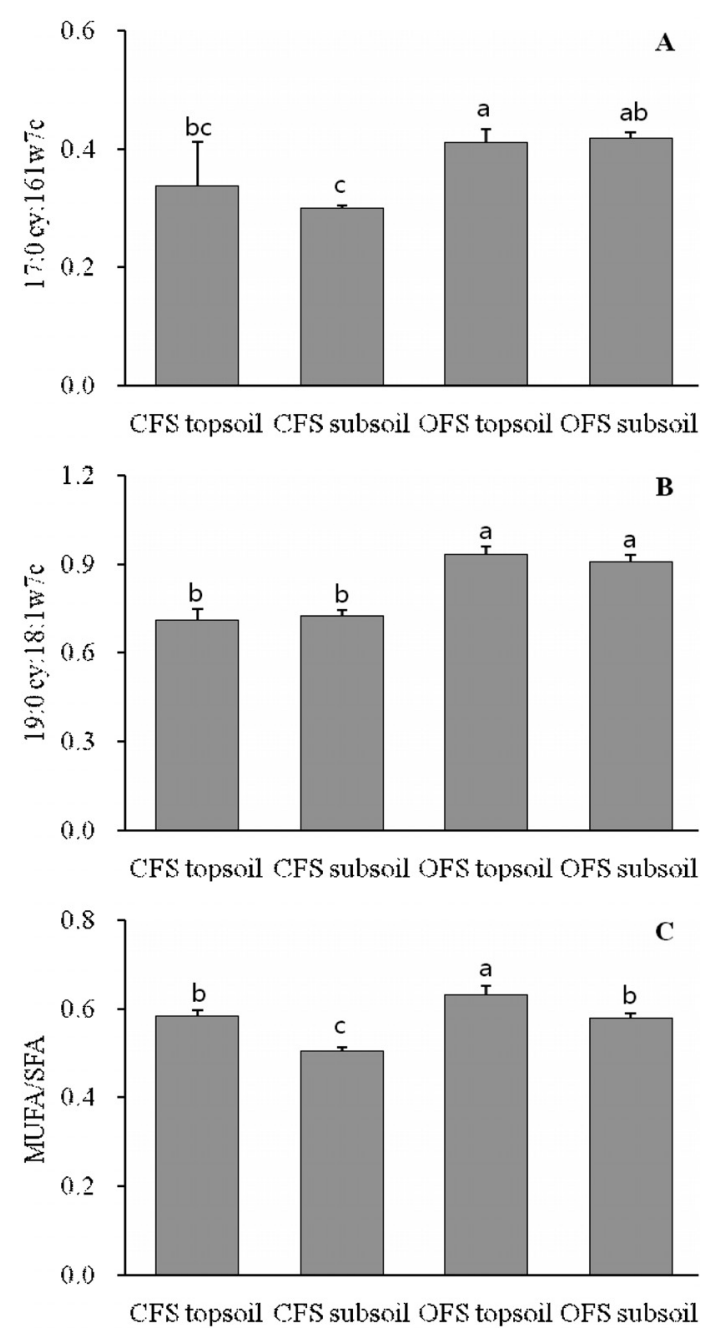

Fig. 1. Ratio of FAMEs, A: cy17:0 to 16:1 $\omega 7 \mathrm{c}$, B: cy19:0 to $18: 1 \omega 7 \mathrm{c}$ and C: MUFA to SFA. Different letters indicate significantly different values $(p<0.05)$. Bars represent one standard deviation of the mean. 
Table 4. Soil microbial community of topsoil and subsoil expressed as \% total FAME at the different cultivation systems.

\begin{tabular}{|c|c|c|c|c|c|c|c|c|}
\hline \multirow[t]{2}{*}{ Biomarker (mol \%) } & \multicolumn{2}{|c|}{$\mathrm{CFS}^{\dagger}$} & \multicolumn{2}{|c|}{$\mathrm{OFS}^{\ddagger}$} & \multirow{2}{*}{$\begin{array}{c}\text { LSD } \\
(p<0.05)\end{array}$} & \multicolumn{3}{|c|}{ Significance $^{\S}$} \\
\hline & Topsoil & Subsoil & Topsoil & Subsoil & & System & Depth & System $\times$ Depth \\
\hline Bacteria & 29.3 & 30.7 & 30.8 & 30.2 & 0.72 & NS & NS & $* *$ \\
\hline Gram-positive bacteria & 15.2 & 16.5 & 15.4 & 15.6 & 0.47 & $*$ & $* *$ & $* *$ \\
\hline Gram-negative bacteria & 11.5 & 11.6 & 12.6 & 11.9 & 0.37 & $* * *$ & $*$ & $*$ \\
\hline Actinomycetes & 1.6 & 1.2 & 1.3 & 1.2 & 0.39 & NS & NS & NS \\
\hline Fungi & 17.5 & 13.9 & 16.8 & 16.5 & 0.54 & $* * *$ & $* * *$ & $* * *$ \\
\hline Arbuscular mycorrhizal fungi & 3.9 & 3.5 & 3.5 & 3.2 & 0.42 & $*$ & $*$ & NS \\
\hline Monosaturated fatty acid & 20.4 & 19.1 & 21.8 & 20.7 & 0.74 & $* * *$ & $* * *$ & NS \\
\hline
\end{tabular}

${ }^{\dagger}$ CFS: Conventional farming system, ${ }^{\ddagger}$ OFS: Organic farming system, ${ }^{\S}$ Significant effects were obtained from two-way analysis of variance: *, at $p<0.05 ; * *$, at $p<0.01 ; * * *$, at $p<0.001$ and NS, not significant.

Fig. 1, microbial communities in soils under OFS were significantly higher ratios of cy 17:0 to $16: 1 \omega 7 \mathrm{c}$, cy19:0 to $18: 1 \omega 7 \mathrm{c}$, and MUFA to SFA compared to CFS $(p<0.05)$. A lower cyclopropyl precursor ratio has been associated with an increase in bacterial growth rates and a decrease in carbon limitation (Bossio and Scow, 1998; Kieft et al., 1997). Lower ratios of cy 17:0 to $16: 1 \omega 7 \mathrm{c}$ and cy 19:0 to $18: 1 \omega 7 \mathrm{c}$ were found in the CFS soils than the OFS soils (Fig. 1 A and B), indicating that microbial stress decreased (Mechri et al., 2010). Those ratios are proposed indicator of bacterial stress as accumulation of cyclopropyl fatty acids was observed in response to various stresses, including nutrient and oxygen depletion, low pH, and desiccation (Guckert et al., 1986; Grogan and Cronan, 1997). Petersen et al. (2002) found that this stress indicator was related to soil temperature and that the ratio increased in soil under the hot and dry summer months in response to more extreme environmental conditions. Therefore, higher cyclopropyl fatty acids in topsoil and subsoil with OFS were considered to affect by high level of organic matter and low level of water contents (Table 1 and 2). The ratio of MUFA to SFA has been tied to nutrient availability. In pure culture studies this ratio decreased in Gram-negative bacteria subjected to starvation conditions (Kieft et al., 1997; Guckert et al., 1986). In our study (Fig. 1c), the ratio of MUFA/ SFA was higher in OFS due to organic input to the soil (Bossio et al., 1998; Lundquist et al., 1999).

The soil microbial communities of CFS and OF expressed as \% total FAMEs were shown in Table 3. The soil microbial communities of different farming systems showed highly significant Gram-negative bacteria $(p<0.001)$, fungi $(p<0.001)$, Gram-positive bacteria $(p<0.05)$, and AMF $(p<0.05)$, but total bacteria and actinomycetes were not significant. The average of AMF in CFS soils was $3.7 \%$ of the microbial community compared with $3.4 \%$ in OFS soils. In the deeper soil, microbial communities of OFS were significantly increased fungi $(p<0.05)$ and MUFA $(p<0.05)$ compared with those of CFS, whereas Gram-positive bacteria $(p<0.05)$ was significantly decreased. Bossio et al. (1998) have shown that different farming regimes such as different organic inputs, influence fatty acids profiles and MUFA increase with organic input to the soil. It must be noted that in our study, there was a strong effect of different cultivation systems on abundances of MUFA. As evidence for OFS in controlled horticultural land, fungi have been shown to be more sensitive to changes in environmental conditions than bacteria (Guerrero et al., 2005; Hamman et al., 2007), possibly explaining the different cultivation system effects (Table 3 and 4). Also, the interaction between different farming system and soil depth about soil microbial communities showed significant bacteria $(p<0.01)$, Gram-positive bacteria $(p<0.01)$, Gram-negative bacteria $(p<0.05)$, and fungi $(p<0.001)$.

Relationship between environmental variables and microbial community structure In order to explain the effect of organic farming system on soil microbial community structure, the principal component analysis (PCA) was applied for all individual FAMEs of soil samples derived from different cultivation systems and at each sampling depth. Coordinates of soil samples on the two first principal components were plotted. The first variable accounted for $54.3 \%$, while the second for $27.3 \%$, respectively (Fig. 2A). The PC1 of the PCA separated the samples from CFS and OFS, while the 

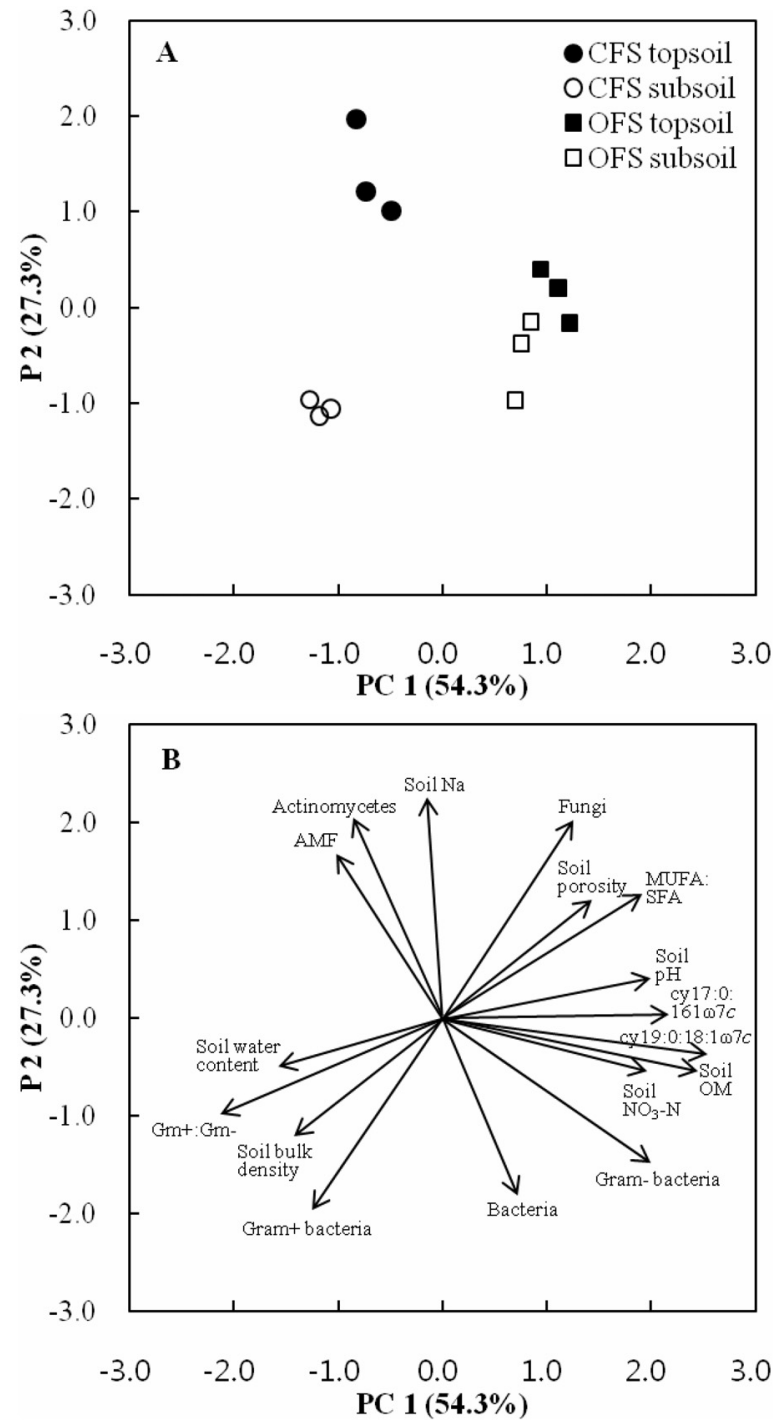

Fig. 2. Principal component analysis between soil microbial communities and soil physicochemical properties. CFS: conventional farming system, OFS: organic farming system.

PC2 of the PCA separated the samples from topsoil and subsoil. The data demonstrated that clear differences in fatty acid composition at each sampling depth were obtained in CFS and OFS. These findings suggest that organic system had the potential to change microbial community structure. To obtain detailed information about the factors that were responsible for the separation of different cultivation systems, correlations between the variables and the factors were calculated (Fig. 1B). The actinomycetes and AMF were significantly correlated with EL-FAME in variation topsoil in CFS, and soil water content, Gram-positive to Gram-negative bacteria ratio, soil bulk density had significant correlation with EL-FAME variation in subsoil in CFS. Steenworth et al (2003) showed that differences in soil microbial community composition of agro-ecosystems were highly correlated with soil $\mathrm{pH}$ and soil management factors that influence resource ( $\mathrm{N}$ and water) availability. Also, Drenovsky (2004) found differences in the microbial community with changes in soil organic matter and soil water content in California agricultural soils. EL-FAMEs with the positive eigenvector coefficients for $\mathrm{PC} 1$ in Fig. 2B were cy17: 0 to $16: 1 \omega 7 \mathrm{c}$ ratio, cy19:0 to $18: 1 \omega$ $7 \mathrm{c}$ ratio, soil $\mathrm{pH}$, soil organic matter, and soil $\mathrm{NO}_{3}-\mathrm{N}$ content. In particular, factor loadings indicated that cy 19:0 to $18: 1 \omega 7 \mathrm{c}$ ratio was heavily weighted on PC1. These findings suggest that the shifting cy19:0 to 18:1 $\omega 7 \mathrm{c}$ ratio should be considered as potential factors responsible for the clear microbial community differentiation observed between different cultivation systems and soil depth in controlled horticultural land. Further work is needed to determine by EL-FAME analysis if the new microbial activity affected organic farming system.

\section{Conclusion}

This study has led to an increasing interest in OFS because it may reduce some of the negative effects of CFS on the environment. In our experimental fields, organically managed soils exhibit greater biological activity than the conventionally managed soils. Higher organic matter content in OFS reduced soil bulk density which in turn increased the soil porosity. Generally, soil chemical properties in OFS were higher than those of CFS, but EC value in OFS was significantly lower than that of CFS. Soil microbial biomass of OFS was approximately 1.3 times in topsoil and 1.8 times in subsoil higher than those of CFS. Lower ratios of cy17:0 to $16: 1 \omega 7 \mathrm{c}$ and cy19:0 to $18: 1 \omega 7 \mathrm{c}$ were found in the CFS soils than the OFS soils, indicating that microbial stress decreased. The ratio of MUFA/SFA was higher in OFS due to organic input to the soil. In principal components analysis (PCA), the first variable accounted for $54.3 \%$, while the second for $27.3 \%$, respectively. Our findings suggest that the shifting cy19:0 to $18: 1 \omega 7 \mathrm{c}$ ratio should be considered as potential factors responsible for the clear microbial community differentiation observed between different cultivation systems and soil depth in controlled horticultural land. 


\section{References}

Allison, F.E. 1973. Soil organic matter and its role in crop production. Elseviere, New York, USA.

Altieri, M.A. 2002. Agroecology: the sceience of natural resource managemen for poor farmers in marginal environments. Agriculture, Ecosystem and Environment 93:1-24.

Balser, T., K.K. Treseder, and M. Ekenler. 2005. Using lipid analysis and hyphal length to quantify AM and saprotrophic fungal abundance along a soil chronosequence. Soil Biol. Biochem. 37:601-604.

Blake, G.R. and K.H. Hartage. 1986a. Bulk density. pp. 363375. In Klute, A. (ed.) Methods of soil analysis. Part 1. $2^{\text {nd }}$ ed. Agron. Monogr. 9. ASA, and SSSA, Madison WI.

Blake, G.R. and K.H. Hartage. 1986b. Particle density. pp. 377-382. In Klute, A. (ed.) Methods of soil analysis. Part 1. $2^{\text {nd }}$ ed. Agron. Monogr. 9. ASA, and SSSA, Madison WI.

Bossio, D.A. and K.M. Scow. 1998. Impacts of carbon and flooding on soil microbial communities: phospholipid fatty acid profiles and substrate utilization patterns. Microb. Ecol. 35:265-278.

Bossio, D.A., K.M. Scow, N. Gunapala, and K.J. Graham. 1998. Determinants of soil microbial communities: effects of management, season and soil type on phospholipid fatty acid profiles. Microb. Ecol. 36:1-12.

Bradleya, K., A. Rhae, R.A. Drijberb, and J. Knopsc. 2006. Increased $\mathrm{N}$ availability in grassland soils modifies their microbial communities and decreases the abundance of arbuscular mycorrhizal fungi. Soil Biol. Biochem. 38:1583-1595.

Buyer, J.S. and L.E. Drinkwater. 1997. Comparison of substrate utilization assay and fatty acid analysis of soil microbial communities. J. Microbiol. Meth. 30:3-11.

Cassel, D.K. 1982. Tillage effects on soil bulk density and mechanical impedance. p. 45-67. In P.W. Unger and D.M. Van Doren (ed.) Predicting tillage effects on soil physical properties and processes. ASA Spec. Publ. 44. ASA and SSSA, Madison, WI.

Cavigelli, M.A., G.P. Robertson, and M.J. Klug. 1995. Fatty acid methyl ester (FAME) profiles as measures of soil microbial community structure. Plant Soil, 170:99-113.

Clark, M.S., W.R. Horwath, C. Shennan, and K.M. Scow. 1998. Changes in soil chemical properties resulting from organic and low-input farming practices. Agron. J. 90:662-671.

Cobb, D., R. Feber, A. Hopkins, L. Stockdale, T. O’Riordan, B. Clements, L. Firbank, K. Goulding, S. Jarvis, and D. Macdonald. 1999. Intergrating the environmental and economic consequences of converting to organic agriculture: evidence from a case study. Land Use Policy 16:207-221.

Drenovsky, R.E. 2004. Soil water content and organic carbon availability are major determinants of soil microbial community composition. Microb. Ecol. 48:424-430.

Fries, M.R., G.D. Hopkins, P.L. McCarty, L.J. Forney, and J.M. Tiedje. 1997. Microbial succession during a field evaluation of phenol and toluene as the primary substrates for trichloroethene cometabolism. Appl. Environ. Microbiol. 63:1515-1522.

Frostegård, Å., A. Tunlid, and E. Bååth. 1993. Phospholipid fatty acid composition, biomass and activity of microbial communities from two soil types experimentally exposed to different heavy metals. Appl. Environ. Microbiol. 59:3605-3617.

Frostegård, Å. and E. Bååth. 1996. The use of phospholipid fatty acid analysis to estimate bacterial and fungal biomass in soil. Biol. Fertil. Soils 22:59-65.

Graham, J.H., N.C. Hodge, and J.B. Morton. 1995. Fatty acid methyl ester profiles for characterization of glomalean fungi and their endomycorrhizae. Appl. Environ. Microbiol. 61: 58-64.

Grogan, D.W. and J.E. Cronan. 1997. Cyclopropane ring formation in membrane lipids of bacteria. Microbiol. Mol. Biol. Rev. 61:429-441.

Guckert, J.B., M.A. Hood, and D.C. White. 1986. Phospholipid ester-linked fatty acid profile changes during nutrient deprivation of Vibrio cholerae: increases in cis/trans ratio and proportions of cyclopropyl fatty acid. Appl. Environ. Microbial. 52:794-801.

Guerrero, C., J. Mataix-Solera, I. Gomez, F. Garcia-Orenes, and M.M. Jordan. 2005. Microbial recolonization and chemical changes in a soil heated at different temperatureas. Int. J. Wildland Fire 14:385-400.

Haldeman, D.L., P.S. Amy, D.C. White, and D.B. Ringelberg. 1994. Changes in bacteria recoverable from subsurface volcanic rock samples during storage at $4^{\circ} \mathrm{C}$. Appl. Environ. Microbiol. 60:2697-2703.

Hamel, C., K. Hanson, F. Selles, A.F. Cruz, R. Lemke, B. McConkey, and R. Zentner. 2006. Seasonal and long-term resource-related variations in soil microbial communities in wheat-based rotations of the Canadian prairie. Soil Biol. Biochem. 38:2104-2116.

Hamman, S.T., I.C. Burke, and M.E. Strombeerger. 2007. Relationships between microbial community structure and soil environmental conditions in a recently burned system. Soil Biol. Biochem. 39:1703-1711.

Ibekwe, A.M. and A.C. Kennedy. 1998. Fatty acid methyl ester (FAME) profiles as a tool to investigate community structure of two agricultural soils. Plant Soil 206:151-161.

Islam, M.R., P. Trivedi, P. Palaniappan, M.S. Reddy, and T. Sa. 2009. Evaluating the effect of fertilizer application on soil microbial community structure in rice based cropping system using fatty acid methyl esters (FAME) analysis. World J. Microb. Biot. 25:1115-1117.

Johnston, A.E. 1986. Soil organic matter, effects on soils and crops. Soil use manage. 2:97-105.

Kieft, T.L., E. Wilch, K. O'connor, D.B. Ringelberg, and D.C. White. 1997. Survival and phospholipid fatty acid profiles of surface and subsurface bacteria in natural sediment microcosms. Appl. Environ. Microbiol. 63:1531-1542.

Kroppenstedt, R.M. 1985. Fatty acids and menaquinone analysis of actinomycetes and related organisms. In: Goodfellow M, D.E. Minnikin (eds) Chemical methods in bacterial systematic. Academic, London, pp. 173-199.

Lundquist, E.J., K.M. Scow, L.E. Jackson, S.L. Uesugi, and C.R. Johnson. 1999. Rapid response of soil microbial communities from conventional, low input, and organic farming systems to a wet/dry cycle. Soil Biol. Biochem. 31:1661-1675. 
Macalady, J.L., M.E. Fuller, and K.M. Scow. 1998. Effects of metam sodium fumigation on soil microbial activity and community structure. J. Environ. Qual. 27:54-63.

Mäder P., A. Fließbach, D. Dubois, L. Gunst, P. Fried, and U. Niggli. 2002. Soil fertility and biodiversity in organic farming. Science 296:1694-1697.

Mechri, B., H. Chehab, F. Attia, F.B. Mariem, M. Braham, and M. Hammami. 2010. Olive mill wastewater effects on the microbial communities as studied in the field of olive trees by analysis of fatty acid signatures. Eur. J. Soil Biol. 46:312-318.

NIAST. 2000. Methods of analysis of soil and plant. National Institute of Agricultural Science and Technology, Suwon, Korea.

Oehl F., E. Sieverding, K. Ineichen, P. Mader., T. Boller, and A. Wiemken. 2003. Impact of land use intensity on the species diversity of arbuscular mycorrhizal fungi in agroecosystems of central europe. Appl. Environ. Microbiol. 5:2816-2824.

Olsson, P.A., R. Francis, D.J. Read, and B. Söderström. 1998. Growth of arbuscular mycorrhizal mycelium in calcareous dune sand and its interaction with other soil micro-organisms as estimated by measurement of specific fatty acids. Plant Soil 201:9-16.

Patra, A.K., X. Le Roux, S.J. Grayston, P. Loiseau, and F. Louault. 2008. Unraveling the effects of management regime and plant species on soil organic carbon and microbial phospholipid fatty acid profiles in grassland soils. Bioresource Technol. 99:3545-3551.

Pankhurst, C.E., A. Pierret, B.G. Hawke, and J.M. Kirby. 2002. Microbiological and chemical properties of soil associated with macropores at different depths in a red-duplex soil in NSW Australia. Plant soil 238:11-20.

Pennanen, T. 2001. Microbial communities in boreal coniferous forest humus exposed to heavy metals and changes in soil pH-a summary of the use of phospholipids fatty acids, Biolog ${ }^{\circledR}$ and 3H-Thymidine incorporation methods in field studies. Geoderma 100:91-126.

Petersen, S.O., P.S. Frohne, and A.C. Kennedy. 2002. Dynamics of a soil microbial community under spring wheat. Soil Sci. Soc. Am. J. 66:826-833.
Rajendran, N., O. Matsuda, Y. Urushigawa, and U. Simidu. 1994. Characterization of microbial community structure in the surface sediment of Osaka Bay, Japan, by phospholipid fatty acid analysis. Appl. Environ. Microbiol. 60:248-257.

Reganold, J.P., L.F. Elliott, and Y.L. Unger. 1987. Long-term effects of organic and conventional farming on soil erosion. Nature 330:370-372.

Ritchie, N.J., M.E. Schutter, R.P. Dick, and D.D. Myrold. 2000. Use of length heterogeneity-PCR and FAME to characterize microbial communities in soil. Appl. Environ. Microbiol. 66:1668-1675.

SAS. 2006. SAS enterprise guide Version 4.1. SAS Inst., Cary, NC.

Schutter, M.E. and R.P. Dick. 2000. Comparison of fatty acid methyl ester (FAME) methods for characterizing microbial communities. Soil Sci. Soc. Am. J. 64:1659-1668.

Siciliano, S.D. and J.J. Germida. 1998. Biolog analysis and fatty acid methyl ester profiles indicate that pseudomonad inoculants that promote phytoremediation alter the root-associated microbial community of Bromus biebersteinii. Soil. Biol. Biochem. 30:1717-1723.

Stark, C., L.M. Condron, A. Stewart, H.J. Di, and M. O'Callaghan. 2007. Influence of organic and mineral amendments on microbial soil properties and processes. Appl. Soil Ecol. 35:79-93.

Sttenworth, K.L., L.E. Jackson, F.J. Calderon, M.R. Stromberg, and K.M. Scow. 2003. Soil microbial community composition and land use history in cultivated and grassland ecosystems of coastal California. Soil Biol. Biochem. 35:489-500.

Torjusen H., G. Lieblein, M. Wandel, and C.A. Francis. 2001. Food system orientation and quality among consumers and producers of organic food in Hedma country, Norway. Food Qual. Prefer.12:207-216.

Wright, S.F., J.L. Starr, and I.C. Paltineanu. 1999. Changes in aggregate stability and concentration of glomalin during tillage management transition. Soil Sci. Soc. Am. J. 63: 1825-1829.

Zelles, L. 1997. Phospholipid fatty acid profiles in selected members of soil microbial communities. Chemosphere 35: 275-294. 